\title{
Szkoła wspierająca twórczość Studium przypadku Priory School w Wielkiej Brytanii
}

\section{Wstęp \\ Creative Partnerships - rządowy program wspierania twórczości}

Wspieranie kreatywności może stanowić jeden z głównych celów realizowanych przez rząd. Dzieje się tak w Wielkiej Brytanii, gdzie od roku 2002 funkcjonuje systemowy program wspierania kreatywności o nazwie Creative Partnerships (CP). Program powstał jako odpowiedź na opublikowany w 1999 r. raport All our Futures wydany przez National Advisory Committee on Creative and Cultural Educations. Raport ten wskazywał konieczność wprowadzenia ogólnokrajowych rozwiązań w edukacji, które stworzą warunki rozwijania potencjału twórczego każdego dziecka, co ma przyczynić się do osiągnięcia sukcesu całego kraju ${ }^{1}$. Wśród wniosków sformułowanych przez autorów był między innymi taki, że zbyt duży nacisk kładzie się w kraju na nauczanie matematyki i języka angielskiego, co nie przekłada się na stwarzanie możliwości rozwijania przez dzieci kreatywności, która zapewne będzie niezbędna w dynamicznie zmieniającym się świecie

Pilotażowy program funkcjonował przez 2 lata w 16 szkołach, a po roku 2004 został rozpowszechniony w Wielkiej Brytanii. Od 2002 r. programem zostało objętych ponad 1 milion uczniów wszystkich poziomów edukacji, ponad 90000 nauczycieli i ponad 54000 rodziców w ok. 8500 projektów. Wspomniany program opiera się na założeniu, że twórczości można uczyć, a nauczyciele mogą być twórczy w nauczaniu (por. Uszyńska-Jarmoc, 2005; Szmidt, 2007). Co ważne,

\footnotetext{
${ }^{1}$ Raport dostępny jest na stronie http://www.cypni.org.uk/downloads/alloutfutures.pdf.
} 
mogą również doceniać twórcze osiągnięcia swoich uczniów. Rolą nauczycieli jest m.in. rozpoznawanie przejawów twórczości i organizowanie warunków, w których te będą mogły być realizowane.

W Wielkiej Brytanii utworzono regionalne oddziały rządowe, których zadaniem jest koordynowanie działań szkół i przedszkoli uczestniczących w projekcie, stwarzanie warunków do wymiany informacji pomiędzy placówkami, pozyskiwanie partnerów współpracujących z nimi, promowanie projektu na danym terenie oraz obsługa finansowa regionu. Szkoły i przedszkola przystępujące do realizacji programu dostają się pod opiekę agenta (creative agent), który wspiera je we wprowadzaniu zmian. Podział obowiązków pomiędzy biurem brytyjskim, oddziałami regionalnymi, szkołami a agentami przedstawia poniższa tabela.

Tabela 1

Podział obowiązków pomiędzy realizatorami programu Creative Partnerships

\begin{tabular}{|c|c|c|c|}
\hline $\begin{array}{l}\text { Biuro narodowe } \\
\text { CP }\end{array}$ & $\begin{array}{c}\text { Biuro regionalne } \\
\mathrm{CP}\end{array}$ & Szkoła & Agent \\
\hline $\begin{array}{l}\text { - przekazuje szko- } \\
\text { łom granty po- } \\
\text { krywające koszty } \\
\text { - opłaca lub prze- } \\
\text { kazuje szkołom } \\
\text { fundusze na opła- } \\
\text { cenie agentów } \\
\text { - ustala zasady } \\
\text { finansowania } \\
\text { i prowadzenia } \\
\text { projektu } \\
\text { - sprawuje opiekę } \\
\text { nad narodową } \\
\text { siecią szkół }\end{array}$ & $\begin{array}{l}\text { - pracuje ze szko- } \\
\text { łami nad two- } \\
\text { rzeniem regio- } \\
\text { nalnych sieci } \\
\text { współpracy } \\
\text { - pomaga szkołom } \\
\text { w wyborze ich } \\
\text { agentów } \\
\text { - wspiera agentów } \\
\text { - nadzoruje regio- } \\
\text { nalne działania } \\
\text { podejmowane } \\
\text { przez szkoły }\end{array}$ & $\begin{array}{l}\text { - otrzymuje granty od } \\
\text { biura narodowego } \\
\text { - wybiera agentów przy } \\
\text { wsparciu biura regio- } \\
\text { nalnego, w niektórych } \\
\text { przypadkach - opłaca } \\
\text { ich prace } \\
\text { - współpracuje z biurem } \\
\text { regionalnym przy two- } \\
\text { rzeniu regionalnej sieci } \\
\text { współpracy } \\
\text { - wspiera inne szkoły } \\
\text { w regionie w ich roz- } \\
\text { woju } \\
\text { - rozwija programy } \\
\text { wspierania twórczo- } \\
\text { ści przy współpracy } \\
\text { z agentem } \\
\text { - rozlicza koszty swoich } \\
\text { projektów z biurem } \\
\text { regionalnym i narodo- } \\
\text { wym, w celu otrzyma- } \\
\text { nia zwrot kosztów }\end{array}$ & $\begin{array}{l}\text { - pomaga w rozwija- } \\
\text { niu programów } \\
\text { wspierania twórczo- } \\
\text { ści w szkołach } \\
\text { i w regionie } \\
\text { - w niektórych przy- } \\
\text { padkach jest zaanga- } \\
\text { żowany i opłacany } \\
\text { przez szkołę } \\
\text { - otrzymuje wsparcie } \\
\text { od regionalnego biu- } \\
\text { ra projektu } \\
\text { - stanowi część regio- } \\
\text { nalnego zespołu eks- } \\
\text { pertów } \\
\text { - reprezentuje szkoły } \\
\text { na spotkaniach regio- } \\
\text { nalnego i narodowe- } \\
\text { go biura }\end{array}$ \\
\hline
\end{tabular}

Źródło: oprac. własne.

Pierwszym, najważniejszym zadaniem każdej szkoły jest opracowanie szkolnego planu wspierania kreatywności. Tworzy się go na podstawie bardzo wnikliwej 
analizy szkoły, jej zasobów rzeczowych i osobowych środowiska działania, specyfiki uczniów, ich zainteresowań i osiągnięć. Program ten może podlegać dalszym modyfikacjom, jednak jego pierwotna wersja staje się punktem wyjścia do stawiania celów, jakie szkoła chce osiągnąć. Musi wynikać z realnych potrzeb wszystkich grup społecznych związanych z nią. Powstawanie programu zwykle trwa od 10 do 16 miesięcy i odbywa się przy silnym wsparciu agenta szkoły. Program może objąć takie zagadnienia, jak zmiana sposobu realizacji programu nauczania na „wszerz programu” (cross-curriculum) (por. Thomson, Sefton-Green, 2011), sposoby nauczania przez nauczycieli, metody nauczania przedmiotów w szkole, system wspierania twórczości (np. Lista Umiejętności (Core Skills) w Priory School w Slough czy Koło Kreatywności (Wheel of Creativity) opracowane w Sunderland), sposoby pracy z rodzicami, środowiskiem lokalnym, system kar i nagród, systemy oceniania w szkole, zasady promocji do wyższych klas itd. (oraz wiele innych zagadnień edukacyjnych i wychowawczych). Należy jeszcze raz podkreślić, że zawartość programu wynika zawsze z potrzeb danej placówki.

Realizacja celów i założeń programu odbywa się poprzez tworzenie długoterminowych partnerstw pomiędzy klasami/szkołami/grupami uczniów a profesjonalistami - artystami, naukowcami, architektami, projektantami, inżynierami, kucharzami, ogrodnikami itd., którzy wspierają uczniów w realizacji różnorodnych projektów. Stąd nazwa programu - Creative Partnership. Profesjonaliści dostarczają uczniom wiedzę, doświadczenie i wsparcie, realizacja projektu zależy tylko od wychowanków placówki. Projekty te powinny wynikać z zainteresowań i potrzeb uczniów.

Szkoły i przedszkola wybierają sposób realizacji programu:

- Rozpoznanie szkoly (enquiry schools programme) - forma trwająca rok, obejmująca konkretną grupę uczniów i nauczycieli, dzięki której szkoła może przekonać się, w jaki sposób chce wspierać kreatywność na swoim terenie, ma czas na rozwinięcie metod i technik nauczania kreatywności, a także na przekonanie wszystkich pracowników, nie tylko nauczycieli, do wspólnej pracy. Szkoła otrzymuje grant na zatrudnianie profesjonalnych partnerów w wysokości $£ 3000$, musi również posiadać $£ 1000$ wkładu własnego. Agent jest do dyspozycji szkoły przez 6 dni w ciągu roku;

- Zmienianie szkoły (change school programme) - forma, która musi trwać powyżej trzech lat, obejmująca swoim działaniem wszystkich uczniów i pracowników szkoły, przynosząca trwałe zmiany w wizji placówki, jej celach i zamierzeniach. Realizacja partnerstw ma na celu rozpoznanie zdolności uczniów, doprowadzenie do pełnej integracji szkoły i środowiska lokalnego oraz wprowadzenia głębokich zmian w postrzeganiu kreatywności w placówce. Szkoły i przedszkola przystępujące do programu są przekonane o wartości kreatywności i chcą ją uczynić najważniejszą wspieraną cechą. Oczekuje się, że szkoły te wprowadzą twórcze uczenie się (creative learning cross-curriculum) przed upływem trzech 
lat od przystąpienia do programu. Dotacja dla placówki wynosi $£ 15000$ każdego roku, a wymagany wkład własny to $£ 5000$. Agent dostępny jest przez 20 dni rocznie. Placówki otrzymują dostęp do systemu, dzięki któremu znajdują inne, realizujące podobne projekty, oraz mogą wyszukać partnerów. Forma jest realizowana obecnie przez ponad 450 placówek;

- Szkoły twórczości (schools of creativity) - forma realizowana do 2011 r. W jej ramach nadawano tytuł szkołom wybitnie wspierającym kreatywność swoich uczniów i pracowników. Tylko 56 placówek w Wielkiej Brytanii posiada ten tytuł. Szkoły te wspierały działalność innych, mniej doświadczonych, rozpowszechniały dobre praktyki, stawały się liderami w regionie, a także przekazywały informacje o konieczności wprowadzania zmian w państwowych przepisach. Szkoły te dostawały 20000 dotacji i 20 dni pracy agenta, którego rekrutowała sama szkoła, aby najlepiej odpowiadał jej potrzebom, musiały natomiast wykazać $£ 5000$ wkładu własnego. Dodatkowo przez 3 dni w roku ze szkołą pracował konsultant edukacyjny, który prezentował wyjątkową wiedzę i umiejętności obejmujące prowadzenie szkoły oraz działanie systemu edukacyjnego w Wielkiej Brytanii. Pomagał szkołom opracować wnioski dla rozwiązań systemowych. Obecnie prowadzone są prace nad nowym sposobem współdziałania z placówkami, które w wybitny sposób wspierają kreatywność.

Poniższa tabela prezentuje liczby szkół biorących udział w różnych formach realizowania programu w zależności od typu placówki.

Tabela 2

Liczba szkół zaangażowanych w program Creative Partnerships w zależności od typu szkoły w 2010 r.

\begin{tabular}{|l|c|c|c|c|c|}
\hline \multicolumn{1}{|c|}{ CP } & Przedszkola & $\begin{array}{c}\text { Szkoły } \\
\text { podstawowe }\end{array}$ & $\begin{array}{c}\text { Szkoły } \\
\text { średnie }\end{array}$ & $\begin{array}{c}\text { Inne } \\
\text { instytucje }\end{array}$ & Suma \\
\hline $\begin{array}{l}\text { Szkoły } \\
\text { przystępujące } \\
\text { do programu }\end{array}$ & 20 & 494 & 235 & 85 & 834 \\
\hline $\begin{array}{l}\text { Szkoły } \\
\text { kreatywności }\end{array}$ & 3 & 24 & 24 & 5 & 56 \\
\hline $\begin{array}{l}\text { Szkoły realizujące } \\
\text { program Zmienianie } \\
\text { szkoły }\end{array}$ & 9 & 238 & 147 & 30 & 469 \\
\hline $\begin{array}{l}\text { Szkoły realizujące } \\
\text { program } \\
\text { Rozpoznanie szkoły }\end{array}$ & 12 & 627 & 136 & 14 & 789 \\
\hline Suma & 44 & 1428 & 542 & 134 & 2148 \\
\hline
\end{tabular}

Źródło: oprac. własne. 
W 2010 r. niezależna instytucja PricewaterhouseCoopers LLP przedstawiła raport o kosztach i zyskach programu Creative Partnerships (The Costs and Benefits of Creative Partnerships), aby przekonać się, jaki wpływ na gospodarkę ma realizacja programu edukacyjnego. $Z$ raportu wynika, że program wygenerował blisko 4 miliardy funtów zysku dla ekonomii Wielkiej Brytanii, co oznacza, że każdy zainwestowany $£ 1$ wart jest $£ 15,30^{2}$. Badania prowadzone natomiast przez NEFER (National Foundation for Educational Research) pokazują, że uczniowie realizujący program osiągają średnio 2,5 oceny wyżej w porównaniu z rówieśnikami z innych szkół w czasie zdobywania General Certificate of Secondary Education (egzamin pisany pod koniec nauki w szkole średniej).

Od 2010 r. trwają prace nad stworzeniem litewskiej wersji programu, którą rząd Litwy planuje wprowadzić w kraju do 2013 r.

\section{Priory School ${ }^{3}$}

Mottem Priory School w Slough, w Wielkiej Brytanii, jest hasło The Children come first zapisane w logo szkoły. Nie są to jednak puste słowa, które dobrze wyglądają w dokumentacji - w tej szkole naprawdę dziecko stoi na pierwszym miejscu.

W 2010 r., przez 30 jesiennych dni, codziennie przyglądałam się pracy tej szkoły w czasie odbywania stażu naukowego ${ }^{4}$. Przed przyjazdem do szkoły wiedziałam o niej tyle, ile udało mi się przeczytać na stronie internetowej, która, trzeba przyznać, nie oddaje atmosfery szkoły. Priory realizuje działania w ramach Creative Partnerships od początku istnienia programu, jest jedną ze szkół posiadających tytuł School of Creativity i najlepiej w regionie realizującą założenia programu. Jest więc Szkołą Twórczości.

Priory School to kompleks budynków, w których działają szkoła podstawowa, przedszkole, żłobek i oddział szkoły podstawowej dla dzieci o specjalnych potrzebach edukacyjnych - relegowanych z innych szkół przynajmniej trzykrotnie. W placówce zatrudnione są aż dwie osoby, które wspierają nauczycieli w stymulowaniu twórczości uczniów i koordynują działania związane z uczestnictwem w CP. Uczestniczą one w podejmowaniu wszystkich decyzji związanych ze szkołą i dbają o to, aby wszystkie sprzyjały kreatywności - od tworzenia programów edukacyjnych, po wybieranie koloru kosza na śmieci.

\footnotetext{
${ }^{2}$ Pełen raport dostępny tu: https://www.creativitycultureeducation.org/data/files/pwc-report-the-costs-and-benefits-of-creative-partnerships-236.pdf.

${ }^{3}$ Opracowano na podstawie wywiadów przeprowadzonych z nauczycielami oraz analizy dokumentów szkoły.

${ }^{4}$ Staż realizowany w ramach projektu „Edukacja-Regiony-Regionalizacja. Program rozwoju Wydziału Nauk o Wychowaniu w ramach strategii rozwoju Uniwersytetu Łódzkiego".
} 


\section{Organizacja nauczania w szkole}

Zgodnie z prawem brytyjskim naukę w szkołach podstawowych dzieci rozpoczynają w 5 roku życia i kończą w 11. Wcześniej mogą uczęszczać do żłobka i przedszkola - 3 i 4-latki oraz do klasy zerowej - 5-latki. Nauczanie w szkole podstawowej może składać się z dwóch etapów. Uczeń może najpierw uczęszczać do tzw. infant school - szkoła dla dzieci w wieku od lat 5 do 7, następnie do tzw. junior school - szkoła dla dzieci od lat 7 do lat 11.

Priory jest szkołą dwupoziomową. W szkole podstawowej uczy się ok. 520 uczniów - po ok. 90 na każdym z sześciu poziomów nauczania, podzielonych na trzy klasy. Młodsze roczniki zwykle są mniej liczne - w klasach uczy się ok. 25 dzieci. Ma to zapewnić wyższy poziom nauczania oraz zostawia możliwość przyjmowania nowych uczniów w trakcie nauki. Klasy nie mogą liczyć powyżej 30 osób. Każdą klasę prowadzi jeden nauczyciel oraz jeden pomocnik nauczyciela, którym może zostać nawet rodzic po odbyciu krótkiego kursu. Na każdym roczniku wybierany jest jeden nauczyciel - lider. Czasem jest to dodatkowa osoba, niekiedy jeden z wychowawców klas. Uczniowie nie są na stałe przypisani do nauczyciela ani nauczyciel do poziomu nauczania. Każdego roku na każdym poziomie 90 uczniów zostaje podzielonych na trzy klasy przy zachowaniu istniejących przyjaźni pomiędzy uczniami. Nauczyciele obowiązkowo zmieniają rocznik, od kilku lat losują go przy założeniu, że nie mogą uczyć na tym samym, na którym w roku poprzednim. Działanie to nie dotyczy oddziału specjalnego zwanego „Domem na drzewie” (Tree House). Nauczanie tam odbywa się w systemie jeden uczeń na jednego nauczyciela lub asystenta nauczyciela. W 2010 r. uczyło się tam 16 uczniów i zatrudnionych było 17 pracowników. W szkole uczą się również dzieci niepełnosprawne, poruszające się na wózkach. Dodatkowo $\mathrm{w}$ ich programie uwzględnione są zajęcia rehabilitacyjne prowadzone na terenie szkoły. Dzieci przyjmowane są do szkoły na podstawie brytyjskich Zasad przyjęć do $s z k o ́ t^{5}$. Aby dziecko mogło przepisać się do Priory z innej szkoły w trakcie edukacji, musi przejść rozmowę z dyrektorem szkoły oraz jedną z nauczycielek twórczości. Rozmowa odbywa się w gabinecie dyrekcji, który w niczym nie przypomina gabinetów w polskich szkołach - uczniowie mogą tam wchodzić, bo drzwi są zwykle otwarte (zamykają się tylko na czas spotkań i jest to znak dla uczniów, że muszą poczekać), na ścianach wiszą prace uczniów, w oknach zaś kolorowe zasłony, goście siadają na wygodnych kanapach, a nie na krzesłach. Dyrektor siedzi na poziomie rozmówcy, nie za biurkiem. Na podstawie rozmowy i krótkich testów oceniany jest poziom kreatywności dziecka. Przy przyjęciu do szkoły nie bierze się pod uwagę ocen. Szkoła cieszy się jednak tak ogromną popularnością, że co roku dysponuje bardzo małą liczbą miejsc wolnych.

${ }^{5}$ School Admissions Code of Practice, http://www.dcsf.gov.uk/sacode 


\section{Okolica, budynek i wnętrze}

Priory School jest szkołą miejską Slough - dużego miasta oddalonego o $34 \mathrm{~km}$ na zachód od Londynu. $Z$ uwagi na bardzo dobrą komunikację ze stolicą i niskie ceny wynajmu mieszkań, Slough jest obecnie ogromnym skupiskiem imigrantów. W latach 20. XX w. Slough było dużym ośrodkiem przemysłowym, co widać w architekturze miasta. Centrum to głównie monumentalne zabudo-

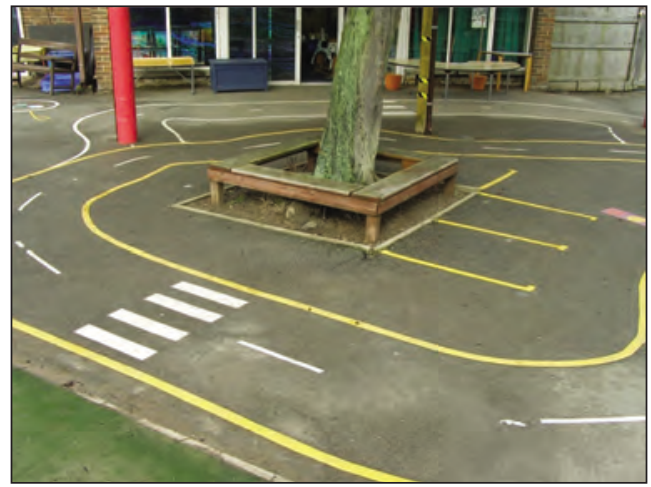

Fot. 1. Otoczenie Priory School

wania fabryczne, hale, magazyny i wieżowce. W Slough swoje siedziby mają obecnie duże koncerny - O2, brytyjskie oddziały Mars Incorporated i Amazon. com. W mieście znajduje się również jedna z siedzib Thames Valley University.

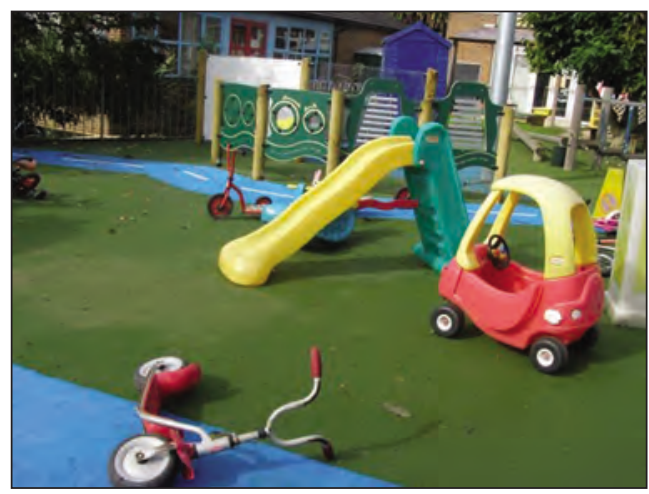

Fot. 2. Otoczenie Priory School

W zdecydowanie innej jednak okolicy mieści się Priory School. Około 200 metrów od szkoły znajduje się granica administracyjna Slough, za którą jest już Burnham - 11-tysięczne, średniowieczne miasteczko otoczone parkami i lasami. Z okien szkoły nie widać więc fabryk, ale drzewa.

Budynki Priory są niskie i bardzo rozległe, a cały teren jest ogrodzony. 
Skomplikowany kształt kompleksu związany jest z ciągłym dobudowywaniem kolejnych elementów. Każdy z roczników zajmuje określoną część budynku. W każdej znajduje się szatnia, łazienki, część wspólna, trzy sale dla klas i pomieszczenia technicznie, wykorzystywane przez nauczycieli do przechowywania dokumentów i pomocy naukowych.

Do szkoły wchodzi się przez duży hol, gdzie znajduje się również gabinet dyrekcji, księgowość oraz sekretariat. Każdy gość wchodzący na teren szkoły musi wpisać się do księgi wejść oraz nosić identyfikator. Przez trzy pierwsze dni pobytu w szkole nie mogłam sama poruszać się po budynku, bo byłam notorycznie ścigana przez pracowników, którzy brali mnie za intruza. Na szczęście czwartego dnia odbywało się tradycyjne, cotygodniowe spotkanie wszystkich nauczycieli i pracowników, na którym zostałam oficjalnie przedstawiona.

Korytarze prowadzą do różnych części budynku przedszkola i żłobka, do gabinetów rehabilitacyjnych, na ogromną stołówkę, która stanowi centrum szkoły, a czasem zamienia się w salę widowiskową, i do innych wyjść. Każdy z roczników korzysta w wyjścia znajdującego się w jego części budynku. Blisko odpowiednich drzwi czekają również rodzice odbierający dzieci. Na pierwszym piętrze znajduje się tylko kilka sal starszych roczników. Budynek z zewnątrz jest nad wyraz estetyczny - pomalowany jednobarwnie na ciepły kolor, z jednakowymi oknami i daszkami nad drzwiami. Mimo to widać, że wokół spędzają czas dzieci.

Kompleks otoczony jest boiskami, placami zabaw, zabawkami i pomocami naukowymi. Miejsca, w których bawią się dzieci, szczególnie młodsze, mają odpowiednio przygotowane podłoże.

Kilka razy w ciągu dnia uczniowie wychodzą na świeże powietrze. W tym czasie otwiera się wszystkie drzwi i okna w szkole. Na boiskach nauczyciele pełnią dyżury, jednak ich zadaniem jest proponowanie różnych form aktywności, a nie tylko pilnowanie porządku. Czyż nie jest to zadziwiający obrazek - nauczycielki grające w chowanego lub w piłkę nożną z uczniami? Na terenach zielonych jest wystarczająca ilość ławek czy pieńków, na których uczniowie mogą siedzieć, a nawet się kłaść. W czasie przerw mogą również korzystać z otwartej pracowni komputerowej.

\section{Dzień w Priory}

Zajęcia lekcyjne rozpoczynają się codziennie o 8:30. W czasie porannego blo$\mathrm{ku}$, trwającego 3 godziny, uczniowie uczęszczają na zajęcia z języka angielskiego, nauk ścisłych i technologii informacyjnych według poziomu zaawansowania w przedmiocie. W każdym momencie mogą zmienić grupę na wyższą lub niższą, jeśli zmieni się ich poziom wiedzy i umiejętności. Uczniowie nie są dyskryminowani z powodu uczęszczania do grupy mniej zaawansowanej z jakiegoś przedmiotu, najczęściej bowiem biorą udział w pracach grupy zaawansowanej $\mathrm{z}$ innego. Jednak nawet uczniowie chodzący na zajęcia do grup najniższych ze wszystkich przedmiotów, nie odczuwają z tego powodu przykrości ze strony innych. O godzinie 11:30 rozpoczyna się godzinna przerwa na lunch - większość uczniów spędza ten 
czas na stołówce, później na boiskach. Kuchnia szkolna przygotowuje posiłki dla dzieci o zróżnicowanych dietach, asystenci nauczycieli pomagają w jedzeniu tym uczniom, którzy mają trudności motoryczne. Stoły i ławki na stołówce są codziennie rozkładane i składane po przerwie, ponieważ sala w każdej chwili może być wykorzystywana przez którąś z klas do swoich zajęć. O godzinie 12:30 rozpoczyna się popołudniowy blok zajęć związany z realizacją szkolnego programu wspierania kreatywności, o godzinie 15:30 większość uczniów wychodzi ze szkoły, zostają tylko ci, którzy uczestniczą w próbach chóru lub dodatkowych zajęciach sportowych.

\section{Uczenie „wszerz”, czyli sposoby nauczania}

W 2005 r. pracownicy szkoły przyjęli szkolny program nauczania, który realizowany jest do dziś. W jego tworzeniu brali udział wszyscy pracownicy szkoły - nie tylko nauczyciele - wsparciem dla szkoły była jej agentka. Punktem wyjścia dla tworzenia programu był cytat pochodzący ze strategii dla szkół podstawowych z 2003 r. - „Edukacja na poziomie podstawowym jest znaczącym etapem w rozwoju dziecka - kształtuje je na całe życie. Jednocześnie powinna dawać narzędzia do uczenia się, ale też rozwijać doświadczanie radości odkrywania, rozwiązywania problemów, bycia twórczym w pisaniu, sztuce, muzyce, rozwijać pewność siebie uczących się i dorastających społecznie i emocjonalnie. Chcemy, aby szkoły jednocześnie podnosiły standardy, nie bojąc się łączenia tego z prowokowaniem uczenia się radości. Naszym celem dla każdej szkoły podstawowej jest łączenie doskonałości w nauczaniu i radością z uczenia" (tłumaczenie własne na podstawie dokumentu wydanego przez brytyjski Department for Education and Skills 'Excellence and Enjoyment - A Strategy for Primary Schools', 2003). W Priory School uznano, że przyjęcie szkolnego programu nauczania twórczości (Creative Learning Curriculum) spowoduje urzeczywistnienie wizji szkoły podstawowej przyszłości. Jednocześnie da możliwość przekazywania wiedzy na wysokim poziomie, ale i skieruje większą uwagę na indywidualne możliwości każdego ucznia, który potrzebuje otwartego, elastycznego i motywującego systemu nauczania, w którym znajdzie się miejsce dla jego uzdolnień. W tym czasie już bardzo dobrze znane były wyniki raportu All our Futures, z którego jasno wynikało, że nauczanie wiedzy akademickiej już nie gwarantuje sukcesu ani w wymiarze jednostkowym, ani narodowym - są dzieci, które posiadają uzdolnienia w innych sferach, które do tej pory nie miały miejsca i możliwości ujawnienia się lub też docenienia w systemie oświaty. Najważniejszym elementem szkolnego programu w Priory jest założenie o egalitarnym charakterze twórczości, co dało podstawę do tworzenia planów obejmujących wszystkich uczniów. Program powstał w wyniku buntu kadry szkoły przeciwko nauczaniu skupionemu tylko wokół przedmiotów, z których uczniowie zdają egzaminy po ukończeniu kolejnych poziomów edukacji (SAT) i nauczycielom znudzonym swoją pracą. W szkole używa się określenia SATs robot, które perfekcyjnie oddaje polski „wyścig szczurów” obserwowany już w szkołach podstawowych. Zapisaną misją szkoły jest „Umożliwić dzieciom 
stanie się odkrywczymi i twórczymi osobami uczącymi się (learners), które osiągają najwyższe możliwe akademickie, artystyczne i techniczne poziomy we wszystkich sferach programu nauczania" [tłumaczenie własne na podstawie dokumentów szkoły]. W związku z tym określono następujące cele:

- osiągnięcie radykalnej zmiany w stylach uczenia się dzieci, jednocześnie wprowadzenie zmian w sposobach nauczania,

- sprzyjanie i inspirowanie do dziecięcej twórczości,

- budowanie pewności siebie dzieci tak, aby mogły przejawiać własną twórczość i nie bały się pokazywać swojej indywidualności,

- rozwinięcie sposobu uczenia przez sztukę.

Nauczyciele stali się odpowiedzialni za dawanie możliwości dzieciom na osiąganie sukcesów w uczeniu się poprzez pełną indywidualizację procesu. Każdy uczeń otrzymuje zadanie na odpowiednim do swoich możliwości poziomie bez względu na płeć, specjalne potrzeby edukacyjne, niepełnosprawność oraz pochodzenie społeczne i kulturowe. Autorski pomysł szkoły na nauczanie przez sztukę będzie szczególnie bliski instruktorom zuchowym pracującym cyklami sprawnościowymi. Każdemu rocznikowi w szkole przypisano 5 tytułów dzieł sztuki (angielski rok szkolny składa się z 6 części, jeden obraz na każdą część, jedna bez przypisanego obrazu). Obraz ten jest punktem wyjścia do planowania wszystkich zajęć programowych w danym czasie. W czasie szóstej części roku nauczyciele i uczniowie danego rocznika sami wybierają obraz, który będzie im służył. Po zakończeniu edukacji każdy uczeń świetnie zna 42 obrazy (dodatkowe 6 poznał w zerówce). Zadziwiająca jest różnorodność obrazów - są tam zarówno ilustracje zawarte w książkach dla dzieci, jak i takie dzieła sztuki, jak Krzyk Edwarda Muncha, Pejzaż z upadkiem Ikara Pietera Bruegela czy Zabawy dziecięce tego samego autora. Na liście znalazł się również portret pary mieszczan pompejskich. Nauczyciel wprowadza w określonym czasie obraz, podając fakty na jego temat, ale i zachęcając uczniów do własnych skojarzeń związanych z dziełem. Działalność klasy na zajęciach popołudniowych przez kilka tygodni związana jest z obrazem - jego elementami, historią, bohaterami, miejscem tworzenia. Każdy fragment popołudniowego bloku zajęć spięty jest klamrą tematyczną z dziełem sztuki. W ramach tych zajęć przekazywana jest wiedza, która w innych szkołach pojawia się na przedmiotach:

- technologie informacyjne i komunikacyjne,

- historia,

- geografia,

- sztuka i projektowanie,

- muzyka,

- taniec,

- drama,

- wychowanie obywatelskie,

- religioznawstwo. 
Dzięki zblokowaniu wiedzy możliwe jest rozwijanie takich umiejętności, jak:

- komunikowanie się,

- praca w grupach,

- wzmacnianie własnych sposobów uczenia się,

- rozwiązywanie problemów,

- wymienianie informacji,

- uzasadnianie swojego zdania,

- dawanie i otrzymywanie informacji zwrotnej.

Dla pełniejszej analizy sposobu działania koncepcji, pokrótce przedstawię cele i treści programowe przekazywane na etapie szkoły podstawowej w dziedzinach oraz zestawię je ze sposobem realizacji na przykładzie roku 6, czyli uczniów w wieku 11 lat, którzy zajmowali się obrazem Portret Henryka VIII autorstwa Hansa Holbeina Młodszego.

\section{Historia}

Wiedza ma zaspokajać dziecięcą ciekawość dotyczącą przeszłości w Wielkiej Brytanii i na całym świecie. Uczniowie powinni analizować wpływ przeszłości na teraźniejszość, poznawać przeszłe cywilizacje, poznawać ich struktury i sposoby działania, politykę, obyczaje i wierzenia. Uczniowie powinni widzieć różnorodność ludzkości, dzięki temu lepiej rozumieć siebie. Uczniowie powinni umieć opisywać wydarzenia z różnych perspektyw - ekonomicznej, politycznej, społecznej, religijnej, kulturowej. Uczą się wykorzystywać różne źródła informacji. Poznają specyficzne słownictwo pozwalające im opisywać przeszłe wydarzenia. Obrazy, które poznają uczniowie, prezentowane są na osi czasu, aby umożliwić uczniom rozumienie jego linearności.

W czasie popołudniowych zajęć uczniowie m.in. oceniali polityczne decyzje Henryka VIII, rysowali drzewo genealogiczne władców Wielkiej Brytanii, zaprojektowali strategiczną grę planszową, której realiami była Anglia czasów Henryka VIII, urządzili bal z tradycyjnymi tańcami z epoki i poznawali zasady savoir-vivre'u, uzupełniali kalendarz Henryka VIII spotkaniami z władcami innych krajów na podstawie wiedzy o ważnych wydarzeniach z życia króla i jego działalności politycznej, np. przy dacie 25 stycznia 1533 r. wpisano - „ślub z moją kochaną Aneczką" (mowa o Annie Boleyn).

\section{Geografia}

Zajęcia z geografii mają prowokować do zadawania pytań dotyczących świata i szukania na nie odpowiedzi. Dają wiedzę o miejscach, przestrzeni, uczą rozumienia map i wykresów. W czasie zajęć $\mathrm{z}$ geografii poruszane są kwestie związane z narodowymi i ogólnoświatowymi problemami - zanieczyszczenie atmosfery, śmieci, wojny, głód. W czasie lekcji uczniowie poznają najbliższą okolicę, region, kraj i kontynent, nawiązują kontakty w ramach regionalnych sieci współpracy. Uczą się podejmowania działań na rzecz środowiska lokalnego. 
Uczniowie rysowali mapę Anglii z czasów Henryka VIII i porównywali ją ze współczesną (najpierw zdobywali informacje o różnych rodzajach map, skalach, przeliczaniu odległości itd.), planowali podróże Henryka VIII, poznawali środki transportu.

\section{Sztuka i projektowanie}

Celem nauczania tego przedmiotu jest stymulowanie kreatywności i wyobraźni poprzez różnorodne eksperymenty z formami, materiałami, kolorami, wzorami i kształtami. Dzięki realizacji programu uczniowie uczą się wyrażać swoje zdanie, kształtują zmysł estetyczny, stają się zaangażowani w podwyższanie poziomu jakości życia swojego i otoczenia. Poznają znaczenia, symbole i konteksty. Uczą się historii sztuki dla umiejętności prognozowania przyszłych trendów. W czasie zajęć uczniowie zajmują się również rękodziełem - szydełkowaniem, szyciem na maszynie, decoupagem, tworzeniem kolaży i witraży oraz projektowaniem i wykonywaniem użytecznych elementów wyposażenia, np. półek, regałów, karmników, skrzynek na kredki. Wszystkie zaprojektowane i zbudowane konstrukcje stanowią wyposażenie szkoły.

W nawiązaniu do tego przedmiotu uczniowie 6 rocznika szyli ubrania wzorowane na tych, jakie nosił Henryk VIII i jego dwór, które wykorzystane zostały w czasie balu. Stroje były bardzo bogato zdobione, a fundusze na materiały niezbędne do ich wykonania uczniowie pozyskali, sprzedając na jesiennym targu warzywa z ogrodu, który prowadzą koło szkoły. Oczywiście większość produktów kupili ich rodzice. $\mathrm{W}$ ramach zajęć popołudniowych powstała również makieta średniowiecznego zamku, którą wykorzystują uczniowie przedszkola do zabaw. Wszyscy uczniowie wyhaftowali swoje inicjały na chustkach do nosa. Uczniowie uzdolnieni plastycznie i technicznie zajęli się przygotowaniem wystroju wnętrz na bal. Na ścianach pojawiły się wielkoformatowe obrazy wzorowane na średniowiecznych portretach. W ramach programu Creative Partnerships szkoła zaprosiła do współpracy lokalną artystkę, która wsparła uczniów w przygotowaniu rękodzieł - gobelinów i nakryć na stoły.

\section{Muzyka i taniec}

Program nauczania muzyki i tańca w Priory School obejmuje naukę gry na różnorodnych instrumentach perkusyjnych, dętych i strunowych oraz poznawanie tańców charakterystycznych dla poprzednich epok. Zajęcia umuzykalniające trwają ok. 30 minut i każdy rocznik bierze w nich udział 3 razy w tygodniu w ramach zajęć popołudniowych. Ze względu na swoją specyfikę i mnogość używanych pomocy dydaktycznych, sala muzyczna zajmuje osobny budynek na terenie szkoły. Sala przystosowana jest do nauczania gry na instrumentach oraz do tańczenia - na sali znajdują się lustra, poręcze, krzesła odpowiedniej wielkości oraz instrumenty w odpowiedniej ilości. Wiedza i umiejętności zdobywane w czasie zajęć muzycznych wykorzystywane są podczas innych zajęć popołudniowych, aby zintegrować nauczanie. 
Rocznik szósty szczególnie wykorzystywał wiadomości zdobywane w czasie zajęć muzycznych. Uczniowie poznali kilkanaście tańców z czasów Henryka VIII, które prezentowali w czasie balu. Organizacja wydarzenia wymagała od nich podzielenia się zadaniami muzyczno-tanecznymi - część przygotowała oprawę muzyczną, część dawała popis taneczny, jednak możliwe było połączenie tych aktywności przez zainteresowanych uczniów. Uczniowie sami szukali utworów muzycznych, które uświetniały bal, niektóre wykonywane były na żywo przez nich. W balu wzięli udział członkowie rodzin dzieci, rocznik 5 oraz wszyscy pracownicy szkoły.

\section{Drama}

Nauczanie dramy w angielskich szkołach ma już bardzo długą historię. Nauczyciele w Priory cenią jej możliwości korygowania zachowań, prezentowania poprawnych wzorów, podnoszenia poziomu pewności siebie i otwartości. Dzięki dramie uczniowie w bezpiecznych warunkach ćwiczą umiejętności społeczne, sprawdzają różne możliwości rozwiązywania konfliktów. Co więcej, drama daje możliwości do rozwijania umiejętności prezentowania siebie i ekspresji twórczej. W czasie zajęć z dramy dzieci wykorzystują całą posiadaną przez siebie wiedzę ze wszystkich dziedzin, co wspiera uczenie się holistyczne i ponadprzedmiotowe.

Obraz Portret Henryka VIII był inspiracją do tworzenia bardzo dużej ilości zajęć dramowych ze względu na kontrowersyjność bohatera obrazu. Najważniejsze odbywały się pod koniec cyklu związanego z obrazem, a dotyczące postawy Henryka wobec jego żon. Zajęcia były również formą sprawdzenia zdobytej przez uczniów wiedzy. Uczniowie wcielali się role króla i jego małżonek w czasie wizyty w programie telewizyjnym typu Rozmowy w toku. Żony pytane były przez prowadzącą o podejście ich męża do nich, o sposoby spędzania wolnego czasu, kontakty z innymi ludźmi, zainteresowania, obowiązki wynikające z pełnienia roli żony króla. Henryk VIII natomiast pytany był o swoje motywy postępowania, rodzaje śmierci, na jakie skazywał swoje żony, o dzieci, członków dalszej rodziny, kontakty z władcami innych krajów.

Wszyscy uczniowie zaangażowani byli w zajęcia w różnorodnych rolach - na widowni zasiedli psycholog, policjant, przedstawiciele kościoła katolickiego i anglikańskiego, jeden z uczniów był reżyserem, którego zadaniem było nakręcenie jak najbardziej interesującego materiału, więc przerywał program, aby dawać wskazówki prowadzącym dotyczące zadawania pytań o bardziej „pikantne” szczegóły. Uczniowie nie przygotowywali się specjalnie do zajęć z dramy, wykorzystywali tylko wiedzą zdobytą w czasie kilku tygodni obcowania z czasami Henryka VIII. W czasie programu były łzy niektórych żon, narzekania na nałogi króla, wyznania tych, które nie mogły zajść w ciążę itd. Uczniowie zaprezentowali nadzwyczajną wiedzę i orientację $\mathrm{w}$ warunkach życia Tudorów, a zaangażowanie wszystkich świadczyło o emocjonalnym związku z wiedzą i umiejętnościami zdobytymi w czasie zajęć. 


\section{Wychowanie obywatelskie}

Celem nauczania tego przedmiotu jest przygotowanie aktywnych, świadomych i zainteresowanych życiem społeczności lokalnej obywateli regionu, kraju i świata. Uczniowie zachęcani są do brania udziału w licznych aktywnościach, działaniach na rzecz społeczności, organizowania wydarzeń sportowych, kulturalnych, obchodów świąt i rocznic. Dzięki przejęciu na siebie ról organizatorów, uczniowie stają się bardziej odpowiedzialni, uczą się pracy w grupie i wykorzystywania zasobów lokalnych - instytucji, ludzi i przestrzeni. Realizacja zadań przygotowuje ich do życia w skomplikowanym układzie społecznym, jaki jest charakterystyczny dla podlondyńskiego miasta.

W ramach realizacji programu tego przedmiotu uczniowie 6 rocznika złożyli wizytę w lokalnej drukarni gazety codziennej, rozmawiali z dziennikarzami o sposobach pisania artykułów, newsów i komunikatów prasowych. Skonstruowali artykuł o balu, który organizowali i ukazał się on w gazecie. Przygotowana została mapa instytucji publicznych funkcjonujących w czasach Tudorów i uczniowie szukali ich odpowiedników we współcześnie działających, jednocześnie pozyskując szczegółowe informacje na ich temat. Uczniowie konstruowali symulacje działań pomocowych, jakie mogły mieć miejsce w przypadku np. utraty majątku przez mieszczanina.

\section{Religioznawstwo}

Nauczanie religioznawstwa ma dawać uczniom wiedzę o różnych systemach wiar i wierzeń, które spotykane są na świecie. Jednocześnie uczniowie poznają światopoglądy związane z religiami. Prezentowanie różnorodności w kwestiach wiary ma budować otwartość i tolerancję wobec innych. Jest to szczególnie istotne w środowisku lokalnym - w jednej klasie mogą znaleźć się przedstawiciele nawet kilkunastu religii.

Uczniowie rocznika 6 analizowali rozłam religijny, jaki wprowadził Henryk VIII, i jego dalsze konsekwencje, również dla współczesności. Uczniowie pisali pamiętnik papieża Klemensa VII, w którym opisywali bieżące wydarzenia, porównywali anglikanizm z katolicyzmem i wyznaniami reformowanymi.

\section{Technologie informacyjne i komunikacyjne}

Przedmiot stanowi uzupełnienie wszystkich innych przedmiotów. Elementy projektów podejmowanych $w$ ramach innych dziedzin powinny opierać się o wiedzę i umiejętności z tego zakresu. Przedmiot przygotowuje uczniów do życia w zmieniającym się świecie, dostarcza narzędzi to znajdowania, analizowania, wymieniania i prezentowania informacji. Wysoki poziom umiejętności z tej dziedziny pozwala uczniom na samodzielne zdobywanie wiedzy i poszukiwanie rozwiązań problemów.

Uczniowie 6 rocznika wykorzystywali komputery i narzędzia internetowe do zdobywania wiedzy niezbędnej do realizacji zadań związanych z Henrykiem VIII - odszukiwali fakty, daty, nazwiska i opinie. W Internecie szukali 
inspiracji do strojów z epoki, w sieci znaleźli również lokalną artystkę, która pomagała im w pracach rękodzielniczych. Drzewa genealogiczne Tudrów projektowane były przy użyciu programu komputerowego. Zorganizowano telekonferencję z przedstawicielem kościoła anglikańskiego, w czasie której uczniowie zadawali pytania dotyczące działania kościoła współcześnie.

Powyższe przykłady działań podejmowanych przez uczniów klas VI pokazują, że można zrealizować program nauczania, programując działania interdyscyplinarne, skupione wokół stymulatora, jakim, w tym przypadku, jest dzieło sztuki.

\section{Lista Twórczych Umiejętności, czyli o tym, jak uczyć uczenia się}

Lista Twórczych Umiejętności (Creative Core Skills) to autorski, szkolny program wspierania kreatywności uczniów i nauczycieli. Creative Core Skills powstała na podstawie Koła Kreatywności (The Creativity Wheel) zaprojektowanego w jednej ze szkół w Sunderland w ramach uczestnictwa w CP.

Poszczególne umiejętności twórcze symbolizują obrazki. Obrazki są inne dla uczniów poziomu Key Stage 1 (KS1, 5-7 lat) i Key Stage 2 (KS2, 8-11 lat), aby odpowiadały wiekowi uczniów. Niektóre z obrazków są dodawane na późniejszych etapach edukacji, ponieważ są za trudne dla 5-6-latków. Na poziomie KS2 do obrazków dodane są podpisy, które mają na celu wpierać rozumienie obrazka i zachęcać do dyskusji. W pierwszym roku nauczania uczniowie uczą się rozpoznawać umiejętności i dopasowywać je do obrazków. Służą temu obrazki umieszczone na magnesach, przyczepione do tablicy. Nauczyciele starają się, aby uczniowie zaczęli kształtować w sobie wskazane cechy. W młodszych klasach nauczyciele dysponują powiększonymi wersjami listy. Po każdych zajęciach, również tych z bloku porannego, nauczyciele pytają całą klasę, jakie umiejętności z listy wykorzystywali w czasie lekcji. Zaznaczają odpowiedzi na powiększonej liście. Każdy uczeń dysponuje również swoją wersją listy i przy odpowiedniej umiejętności z listy wstawia datę, kiedy jej użył. Wszystkie sugestie dotyczące używanych umiejętności są przedyskutowane na forum klasy. Uczniowie podają przykłady z zajęć.

Przykładowe hasła $\mathrm{z}$ listy dla roku 1:

- Rób porównania,

- Obserwuj,

- Łącz, dopasowuj,

- Zadawaj pytania,

- Dyskutuj, ucz się od innych,

- Szukaj, odkrywaj, używając komputera,

- Szukaj, odkrywaj, używając książek,

- Rozwiązuj problemy, 
- Odkrywaj, odgrywając role,

- Doświadczaj poprzez zabawę, bądź otwarty na nowe idee, szukaj różnych sposobów działania,

- Używaj różnorodnych pomocy,

- Myśl,

- Słuchaj,

- Eksperymentuj i ryzykuj,

- Pracuj z innymi,

- Łącz, wymieniaj wiedzę.

Pamiętając, że na 1 roku są dzieci 5-letnie, można się zastanawiać, czy 5-latek rozumie słowa użyte w hasłach, okazuje się jednak, że ważniejsze staje się wyrobienie połączeń skojarzeniowych obrazek - zachowanie. Dzieci wiedzą, jaki typ działań kryje się pod każdym z rysunków. Na dalszych etapach edukacji uczniowie intuicyjnie zaczynają używać słów do określania własnych działań. Lista dla KS2 to pary obrazek z podpisem - hasło. Nauczyciele twierdzą, że po ok. 3 miesiącach uczniowie znają znaczenia wszystkich obrazków i mogą posługiwać się nimi do opisywania swojej aktywności w czasie zajęć, co ułatwia im również forma - hasła napisane są w czasie przeszłym, w pierwszej osobie liczby pojedynczej,

Lista haseł dla KS2 to:

- Narysowałam to w myśli,

- Słuchałam różnych spojrzeń na problem,

- Pracowałam w grupie,

- Zadawałam pytania,

- Wypróbowałam wiele różnych sposobów zrobienia czegoś. Wymyśliłam niezwykły sposób zrobienia czegoś. Znalazłam nową metodą zrobienia czegoś,

- Zaufałam swoim przeczuciom,

- Porównywałam i zestawiałam (rzeczy, zjawiska, obiekty). Posegregowałam informacje,

- Połączyłam to, co nowe z tym, co już wiedziałam,

- Odczuwałam przyjemność z uczenia się i dowiadywania nowych rzeczy. To było interesujące,

- Zaryzykowałam. Wypróbowałam nowy pomysł,

- Zauważyłam problem i zmierzyłam się z nim,

- Zatrzymałam się i pomyślałam o swojej pracy. Wymyśliłam coś nowego,

- Osiągnęłam swój cel. Były inne metody osiągnięcia go,

- Patrzyłam uważnie i czyniłam obserwacje.

Kiedy pierwszy raz usłyszałam, że w szkole działają „listy umiejętności”, miałam wątpliwości, czy jest to narzędzie wykorzystywane na co dzień, czy tylko stworzone na potrzeby wypełnienia wymagan do tytułu School of Creativity. $\mathrm{Ku}$ mojemu zaskoczeniu jednak listy funkcjonowały w każdej klasie i stanowiły ważny element każdego spotkania. Nauczyciele mają dowolność w używaniu list 
- większość jednak zaczyna zajęcia od przedstawienia umiejętności, jakie dzisiaj będą wykorzystywane, a kończąc, pyta uczniów, kiedy je zaobserwowali. Uczniowie wypełniają również indywidualne karty.

Tablica z Core Skills wisi na jednym z głównych korytarzy szkolnych, aby każdy uczeń mógł wielokrotnie w czasie dnia na nią patrzeć.

\section{Nauczyciele i ich instrumentarium}

Nie jest łatwo dostać pracę nauczyciela lub asystenta nauczyciela w Priory School. Oprócz posiadania odpowiednich kwalifikacji wynikających z prawa ${ }^{6}$, trzeba jeszcze wykazać się postawą zgodną z oczekiwaną przez dyrekcję i pozostałych pracowników. Nauczyciel w Priory nie jest tym, który przekazuje wiedzę i naucza, ale jest facylitatorem procesu uczenia się uczniów - pomaga, inspiruje, motywuje i wspiera. Nauczyciele pozwalają uczniom popełniać błędy, ryzykować, eksperymentować, krzyczeć, jeśli jest taka potrzeba, realizować zadanie sposobami przez siebie wymyślonymi. W czasie rozmowy z dyrektorem szkoły dowiedziałam się, że pierwszy rok pracy nauczyciela w Priory jest jak, ,jazda na kolejce górskiej bez pasów bezpieczeństwa - nigdy nie wiesz, czym cię zaskoczy uczeń, jak bardzo skomplikowanym sposobem będzie chciał rozwiązać problem, w którą stronę pociągnie cię klasa. Musisz być twardy jak skała, bo jednak jesteś nauczycielem, i jednocześnie giętki jak guma - bo jesteś nauczycielem w Priory School, a tu pozwala się dzieciom być sobą".

W rozmowie kwalifikacyjnej z kandydatem na nauczyciela bierze udział dyrektor, opiekunowie twórczości w szkole, kilku doświadczonych nauczycieli i asystentów oraz, co zaskakujące, przedstawiciele każdego rocznika. Miałam okazję uczestniczyć w jednej z rozmów. Najbardziej zdziwiło mnie to, że rozmowę prowadzili praktycznie uczniowie. Kandydat znalazł się pod deszczem pytań typu „dlaczego niebo jest niebieskie”, „dlaczego wieje wiatr”, „czemu Francuzi nie chcą mówić po angielsku". Na szczęście udzielał poprawnych odpowiedzi, czyli takich, które prowokowały uczniów do samodzielnego poszukiwania rozwiązań problemów. Gdyby chociaż jedna z odpowiedzi była po prostu odpowiedzią na pytanie, niewątpliwie nie mógłby zostać zatrudniony.

Do niezwykle ważnych cech nauczycieli pracujących w Priory należą otwartość, uprzejmość, bardzo wysoki poziom kultury osobistej prezentowany zarówno w kontakcie nauczyciel - uczeń, ale również wśród nauczycieli oraz ogromne poczucie humoru i dystans do siebie. Pytałam nauczycieli, jak by zareagowali w sytuacji, kiedy w czasie przerwy wylaliby na siebie kawę i mieli na koszuli plamę. Najczęściej padały odpowiedzi, że nic, przecież wszyscy mają coś poplamione

${ }^{6}$ Teaching and Higher Education Act 1998. 


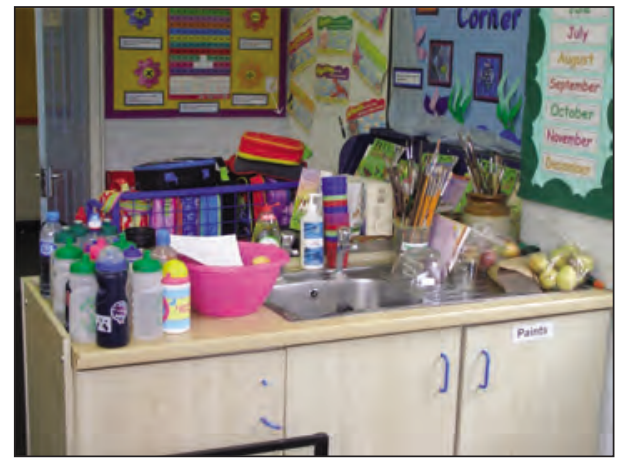

Fot. 3. Wyposażenie klasy

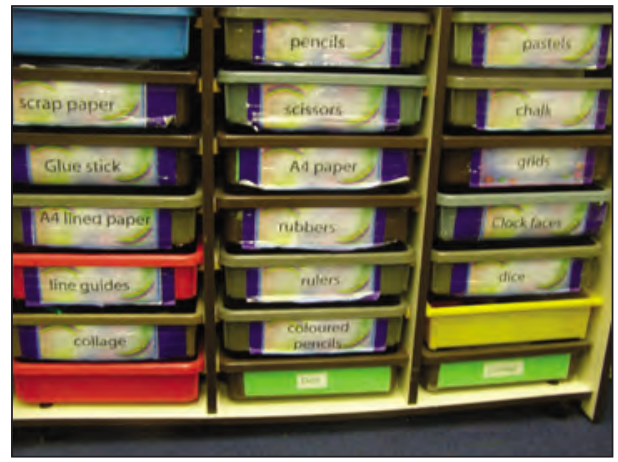

Fot. 4. Wyposażenie klasy

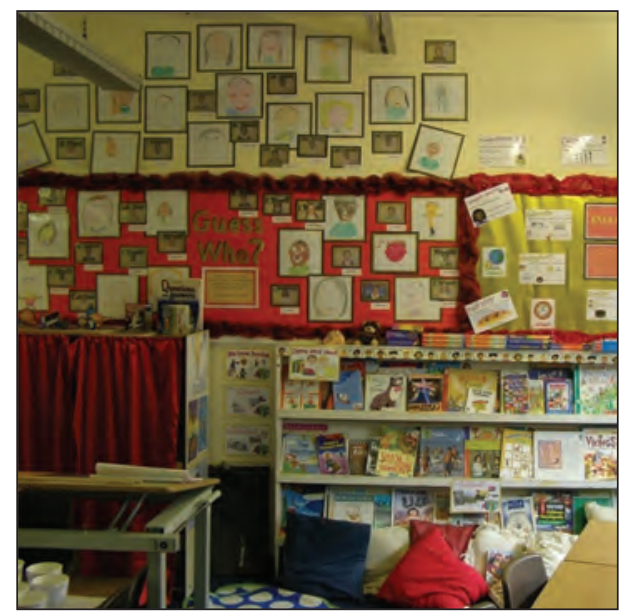

Fot. 5. Wyposażenie klasy

na co dzień - to jest szkoła podstawowa. Połączenie tych cech powoduje, że uczniowie traktują nauczycieli z ogromnym szacunkiem i jednocześnie obdarzają ich dużym zaufaniem. Nauczyciele na bieżąco orientują się w relacjach między uczniami i wspierają ich w rozwiązywaniu konfliktów.

$\mathrm{Na}$ czas mojego pobytu w szkole przypadły coroczne „dni robocze”. Jest to czas, jaki nauczyciele poświęcają na analizowanie swojej pracy, również planowanie na przyszłość. Ponieważ szkoła uczestniczyła w programie CP od początku jego istnienia na zasadach opracowanych kilka lat temu, istniała potrzeba przeanalizowania aktualnych potrzeb środowiska, wyznaczenia kolejnych celów do realizacji. W spotkaniu uczestniczyli wszyscy nauczyciele i asystenci nauczycieli, przedstawiciele biura regionalnego CP, 3 pracowników Uniwersytetu w Exeter, z którym szkoła współpracuje, oraz kilkoro zaangażowanych w działanie szkoły rodziców. Przez ponad 11 godzin wszyscy rozmawiali o tym, jak lepiej i skuteczniej wspierać 
kreatywność uczniów. Drugi dzień roboczy poświęcony był przyjemnościom - nauczyciele brali udział w warsztatach dla nich przygotowanych, poznawali nowości (m.in. makijaż henną, degustacje wina i serów, wykorzystywanie GPSów do gier terenowych, warsztaty zumby, pilatesu i aerobicu), ale również wykonywali prace na rzecz szkoły - malowanie okien, użyźnianie ogrodu, naprawianie płotów. W czasie „dni roboczych” uczniowie zwolnieni są z zajęć szkolnych.

Wydaje się jednak, że najbardziej otwarty i kreatywny nauczyciel nie byłby w stanie osiągać tak dobrych rezultatów nauczania bez odpowiedniej organizacji instytucji, jaką jest szkoła oraz bez poparcia wszystkich jej pracowników. Nie bez znaczenia są również fundusze otrzymane w ramach programu Creative Partnerships, dzięki którym nauczyciele mogą realizować pomysły dzieci.

Dodatkowo na uwagę zasługuje wyposażenie szkoły - każda sala dysponuje ogromnych rozmiarów tablicą multimedialną, nagłośnieniem, białymi tablicami do zapisywania, w każdej klasie na całej powierzchni podłogi jest wykładzina, stoliki i krzesła wykonane są z lekkich tworzyw, które umożliwiają błyskawiczną modyfikację przestrzeni. Dzięki obecności umywalek w każdej z sal, możliwe są zajęcia plastyczne i techniczne. Każda klasa ma swój kącik z pomocami, zwany przez większość dzieci „kącikiem skarbów” (treasure corner).

Znajdują się tam zarówno nożyczki, taśmy klejące, farby, pędzle, kredki itd., ale również guziki, drut, sznurki, cekiny, naklejki, suszone kwiaty, kawałki styropianu, gliny, gipsu itp. Skarby zbierane są przez całą klasę, każdy może do nich coś dołożyć i w każdej chwili z nich korzystać. Najbardziej oczarowały mnie masywne półki z książkami znajdujące się w każdej klasie. Każde zajęcia po przerwie rozpoczynają się od 5-minutowego cichego czytania wybranej książki. Nauczyciele wiedzą, jakie książki aktualnie czytają ich uczniowie, znają je i rozmawiają o nich np. w czasie przerw. Czytanie ma za zadanie wyciszenie uczniów po zabawie, skupienie ich, daje również czas na fizyczny odpoczynek.

\section{Uczniowie}

W czasie pobytu w szkole dobrze poznałam uczniów jednej z klas trzeciego roku, prowadząc dla nich warsztaty twórcze, jak również uczestnicząc w ich zajęciach. Obserwowałam zachowania uczniów, ich stosunek do nauczycieli i pracowników szkoły, relacje między nimi i sposoby rozwiązywania konfliktów, które musiały się pojawić w tak licznej grupie 7-latków. Interesowały mnie sposoby spędzania przez uczniów przerw oraz, oczywiście, ich uczenie się. Najważniejszym wnioskiem obserwacji było to, że uczniowie Priory ubóstwiają swoją szkołę. Kiedy witałam ich rano, widziałam ogromną radość płynącą z faktu, że mogli do niej przyjść. Uczniowie mówili, że czują się w szkole dobrze, lubią nauczycieli i wydaje im się, że nauczyciele ich lubią, wiedzą, że mogą bez skrępowania mówić 


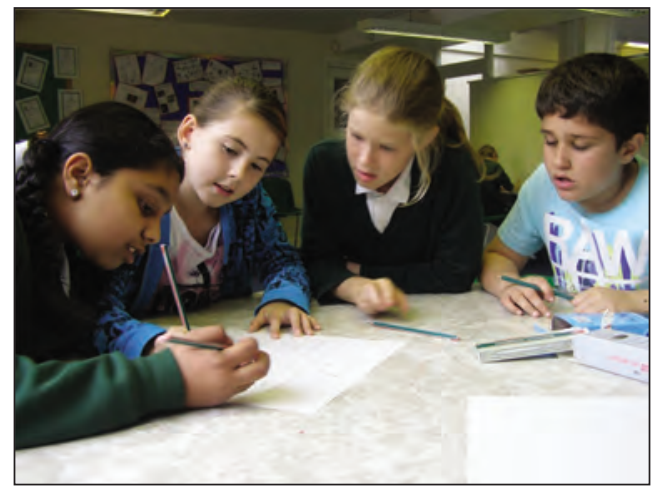

Fot. 6. Uczniowie w trakcie pisania tekstu piosenki

o swoich przemyśleniach, dzielić się pomysłami i planami. Chodzenie do szkoły kojarzy im się z przygodą. W czasie 3-godzinnego bloku popołudniowego uczennica wskazana przez asystentkę nauczyciela jako najbardziej zamknięta w sobie siedziała przy stole łącznie 26 minut, siedziała w innym miejscu niż krzesło (podłoga, parapet, półka z książkami) 41 minut, pozostały czas spędziła, chodząc lub wykonując inne czynności (kucanie, podskakiwanie). Zaintrygowana tymi obserwacjami po powrocie do Polski zadałam te same pytania uczniom klasy II jednej z łódzkich szkół podstawowych - czują się w szkole dobrze, lubią nauczycielkę, ale nie wiedzą, czy ona ich lubi. Nie wolno na lekcjach mówić o swoich pomysłach, chyba że nauczycielka powie, że można podczas wykonywania jakiegoś zadania. Chodzenie do szkoły kojarzy im się z siedzeniem. W czasie 3 godzin zegarowych (czas liczony tylko w czasie lekcji) wybrana w jednakowy sposób uczennica spędziła tylko dwie minuty poza swoim krzesłem i ławką (została poproszona o wytarcie tablicy).

Uczniowie biorą udział w regionalnych i narodowych konkurach przedmiotowych i projektowych, zdobywając bardzo wysokie nagrody. Licznymi sukcesami mogą się szczycić szczególnie członkowie chóru szkolnego, zespołu gitarowego, sportowcy oraz członkowie zespołów projektowych. Konkursy tego typu polegają na określeniu tematyki (np. rozwiązania techniczne problemów środowiska), jednak treść zadania uczniowie poznają dopiero w czasie zawodów (np. zaprojektujcie i wykonajcie urządzenie do zbierania wody pitnej). Uczniowie sami zgłaszają chęć uczestnictwa w konkursie poprzez zebranie zespołu. Szukają innych uczniów, którzy np. posiadają umiejętności techniczne, są specjalistami z odpowiedniego tematu, potrafią podtrzymać dobrą atmosferę w grupie itd. Byłam oszołomiona wiedzą, jaką posiadają uczniowie na temat ról grupowych, bo świadczy to o ich dużej świadomości funkcjonowania zespołu. 


\section{Zakończenie Priory - twórczy raj?}

Wnikliwa analiza dokumentów szkoły oraz wywiady swobodne z nauczycielami pozwalają mi stwierdzić, że szkoła nie jest wolna od wad. Do największych należy mały wpływ nauczycieli i uczniów na listę dzieł sztuki, które stanowią funkcję stymulatorów w czasie zajęć. Lista ta powstała w 2004 r. i od tego czasu nie zmieniła się. Materiały przygotowane do zajęć związanych z kolejnymi obrazami, opracowane przez nauczycieli kolejnych lat, dostępne są wszystkim na wewnętrznej platformie szkoły, co powoduje, że prowadzący zajęcia nie musi wszystkiego robić sam. Niestety ma to wpływ na obniżenie poziomu zaangażowania i zaprzestanie stymulowania twórczości nauczycieli. Cele wyprowadzone w czasie „dni roboczych" pozwalają przypuszczać, że ten stan się zmieni. Nauczyciele chcieli większej dowolności w wybieraniu dzieł sztuki oraz w modyfikowaniu „listy umiejętności”. Postulowali, aby z dużej liczby umiejętności każdy z nich mógł wybrać, jakie stymulowane będą $\mathrm{w}$ danym roku. Nowe zasady dotyczące wyboru obrazów wprowadzone zostały we wrześniu 2011 r., to nauczyciele danego rocznika decydują, jakie obrazy będą wykorzystywane przy założeniu, że nie mogą się one powtarzać w edukacji dziecka.

Tytuł zakończenia zobowiązuje do zapisania ważnej konkluzji tego krótkiego opisu studium jednej, ale za to arcyciekawej szkoły wspierającej twórczość uczniów. Konkluzja może być taka, że Priory School powinna stać się inspiracją dla szkół również w Polsce. Autorskie elementy wspierające kreatywność uczniów i nauczycieli mogą zostać przeniesione na nasz grunt, oczywiście po dokonaniu pewnych modyfikacji. Połączenie interesujących narzędzi, odpowiedniej organizacji szkoły, stylu pracy nauczycieli mających ten sam cel i uczniów chcących się rozwijać, może przynieść tylko dobre efekty.

\section{Literatura}

Szmidt K. J. (2007), Pedagogika twórczości, Gdańskie Wydawnictwo Psychologiczne, Gdańsk.

Uszyńska-Jarmoc J. (2003), Twórcza aktywność dziecka. Teoria - rzeczywistość - perspektywy rozwoju, Trans Humana, Białystok. 